\title{
Tissue Albumin and Water Content in the Early Stages of Vasogenic Brain Edema Formation
}

\author{
MICHAEL P. PASH and W. ARNOLD TWEED
}

\begin{abstract}
SUMMARY: Brain edema (BE) research lacks quantitative regional methods. We modified the method of Pappius and McCann (1969), who used radioactive iodinated $\Pi^{25}$ serum albumin (RISA) as a label for vasogenic $B E$ fluid. To correct for intravascular plasma volume we used $\mathrm{Cr}^{51}$ labelled red blood cells and calculated equivalent extravascular plasma volume (EVPV). The modified RISA method was compared with a standard method for measuring increased tissue water, i.e. the change in wet:dry weights. Anesthetized rabbits were subjected to unilateral cortical freeze injury and sacrificed three hours later. The lesion corresponding to the area of blood brain barrier (BBB) breakdown was delineated by Evan's blue staining. That area and the two adjacent
\end{abstract}

RESUME: La recherche sur l'oedème cérébral manque de méthodes régionales quantitatives. Nous avons modifié la méthode (1969) de Pappius et McCann, qui utilisaient l'albumine sérique marquée à l'iode $I_{125}(R I S A)$ comme indice du fluide de l'oedème cérébral vasogénique. Pour corriger pour le volume plasmique intravasculaire nous utilisons les globules rouges marqués au $\mathrm{Cr}_{51}$ et nous calculons le volume plasmatique extravasculaire équivalent (EVPV). Cette méthode RISA modifiée fut comparée avec une méthode standard de mesure de l'augmentation de l'eau tissulaire: la mesure des modifications des poids secs et humides. Des lapins anesthésiés furent lésés par froid d'un seul cóté du cortex et sacrifiés trois heures plus tard. La lésion correspondant à l'aire où se fait la modification de la barrière hémoencéphalique fut délimitée par coloration au bleu d'Evan. Cette zone et deux pôles

From the University of Manitoba, Department of Anaesthesia, Health Sciences Centre, Winnipeg.

Reprint requests to: Dr. Michael Pash, Dept. of Anaesthesia, Health Science Centre, 700 William Ave., Winnipeg. R3E 0Z3. Canada. poles were sectioned. The contralateral hemisphere was used as the control. Good agreement was found between the two methods. By the modified RISA method, $4.08 \%$ of the wet weight of the injured hemisphere was EVPV while the decrease in dry weight corresponded to $5.56 \%$ edema. In the freeze lesion, however, where $B B B$ breakdown occurred extravascular (EV) protein exceeded EV water, while adjacent to the lesion in the area with intact $B B B, E V$ water exceeded $E V$ protein. This suggests that the diffusion rate for water through brain tissue exceeds that of albumin in the early stages of vasogenic BE formation. We conclude that the modified RISA method is a satisfactory measure of regional vasogenic $B E$ in acute animal experiments.

connexes furent découpés. L'hémisphère contralatéral fut utilisé comme témoin. Il existe une excellente correspondance entre les deux méthodes. Ainsi, par la méthode RISA modifiée, $4.08 \%$ du poids humide de l'hémisphère lésé était EVPV, alors que la diminution du poids sec correspondant à $5.56 \%$ d'oedème. Dans la lésion par engelure, cependant, là où la barrière hémoencéphalique était déficiente. les protéines extravasculaires (EV) dépassaient l'eau $E V$, alors que dans les régions adjacentes intactes, l'eau EV dépassait les protéines EV. Ceci suggère que dans les premiers stages de formation de l'oedème cérébral vasogénique le taux de diffusion de l'eau à travers le tissue cérébral excède celui de l'albumine. Nous concluons donc que la méthode RISA modifiée constitue une mesure satisfaisante de l'oedème cérébral vasogénique régional dans des expériences animales aigues.

\section{INTRODUCTION}

A major problem in brain edema (BE) research is the lack of quantitative regional methods. We report a new method to measure regional vasogenic BE in experimental animals, based on the RISA method of Pappius and McCann (1969), using an intravascular marker to correct for intravascular plasma volume. The method was validated by comparison with the change in wet:dry weights of the tissue. In the course of these experiments, observations pertaining to diffusion rates of water and albumin in the early stages of $\mathrm{BE}$ formation were obtained.

\section{METHOD}

Twelve rabbits, weighing approximately $4 \mathrm{~kg}$ each, were prepared and studied in the following manner:

Anesthesia was induced with pentobarbital sodium, $15 \mathrm{mg} / \mathrm{kg}$, administered intravenously into an ear vein. A tracheostomy was then performed and ventilation was controlled using an Ohio neonatal respirator at settings to keep $\mathrm{pH}$ and $\mathrm{PaCO}_{2}$ within normal limits. The animal was paralyzed with pancuronium bromide $3 \mathrm{mg} \mathrm{I.V.,} \mathrm{and}$ supplemental doses of pancuronium and pentobarbital were given as required.

Catheters were placed in the aorta and interior vena cava through cutdowns on the right femoral artery and vein. Femoral arterial blood pressure and rectal temperature were monitored continuously, while arterial blood gases were measured at regular intervals. Temperature was kept within the normal range $\left(37-39^{\circ} \mathrm{C}\right)$ with a radiant heat lamp and a heating pad. Mean arterial blood pressure (MABP) was maintained at $80-100$ torr by infusions of $15-20 \mathrm{ml}$ boluses of 
normal saline. A $12 \mathrm{~mm}$ burr hole was then made over the left parietal hemisphere for the freeze lesion, care being taken to keep the dura intact.

Fifteen $\mathrm{ml}$ of blood were withdrawn from the femoral arterial line and the red cells labelled with $\mathrm{Cr}^{51}(50 \mu \mathrm{Ci})$. After agitating for 10 minutes the cells were spun down, the plasma removed, and the volume reconstituted with normal saline. In this preparation $99 \%$ of the $\mathrm{Cr}^{51}$ was bound to red blood cells. The $15 \mathrm{ml}$ of $\mathrm{Cr}^{51}$ labelled red blood cells and serum albumin labelled with I $^{125}(5 \mu \mathrm{Ci})$ (RISA) were then injected into the fermoral venous line and timing was begun at this point.

After 1 hour, the first samples were drawn for $\mathrm{Cr}^{51}$ and $\mathrm{I}^{125}$ counts in blood and serum and arterial blood gas determination. Then a freeze lesion 1 $\mathrm{cm}$ in diameter at $-50^{\circ} \mathrm{C}$ for 10 seconds was made on the left parietal hemisphere through the previously placed burr hole. Second and third blood and serum samples and arterial blood gases were taken at 2 and 3 hours. Fifteen minutes before the end of the experiment, $10 \mathrm{ml}$ of $2 \%$ Evan's blue dye was injected intravenously to demarcate the area of blood brain barrier (BBB) breakdown.

At 3 hours after injection of isotopes and 2 hours after the freeze lesion, the animal was sacrificed by intravenous
EXPERIMENTAL MODEL Rabbit Brain

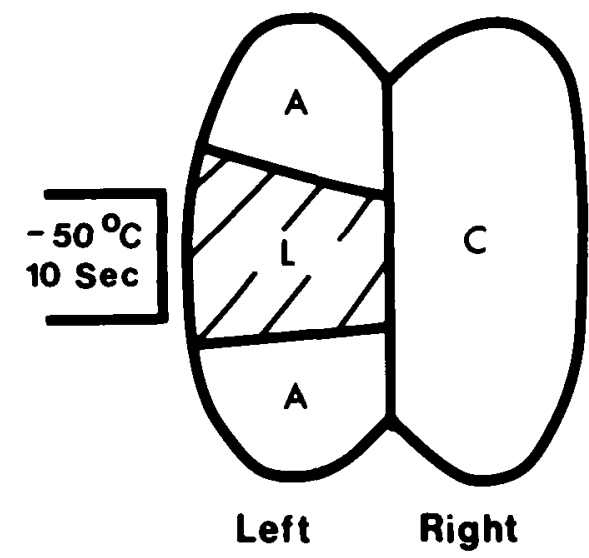

Figure I - Schematic diagram of rabbit brain, showing area of the freeze lesion (L), the two adjacent areas (A), and the control hemisphere (C).

injection of saturated $\mathrm{KCl}$ solution. The brain was quickly removed and each hemisphere was divided into 3 sections in a humidity chamber.

In the injured hemisphere one section (L) (see Figure 1) consisted of blue stained tissue, the tissue with BBB breakdown in the area of the freeze lesion. The other two sections (A) consisted of the unstained adjacent poles of the hemisphere. Corresponding divisions were made in the control (C) hemisphere. Each section was weighed immediately, placed in glass tubes, and counted in a Chicago Nuclear gamma scintillation counter. The blood and serum samples were similarly treated. After counting, the tissue samples were dried at $42^{\circ} \mathrm{C}$ to a constant weight, reweighed, and percent tissue solids calculated for each section.

The extravascular plasma volume (EVPV) in each section were calculated using the following formula:

EVPV $=\left(\frac{I^{125} \text { counts } / \text { gm tissue }}{I^{125} \text { counts } / \text { gm serum }}\right.$

$\left.-\frac{C r^{51} \text { counts } / \mathrm{gm} \text { tissue }}{\mathrm{C} \mathrm{r}^{51} \text { counts } / \mathrm{gm} \text { blood }}\right) \times(1-\mathrm{Hct})$

The difference in EVPV between each section of the injured hemisphere and the average of the control hemisphere (excess EVPV) was compared to the percent decrease in tissue solids in the same sections.

A similar set of experiments was done on 5 rabbits, but with no burr hole or freeze lesion (unoperated controls). These were done to compare EVPV in untraumatized brains with that of the control hemisphere of the lesioned rabbits, and to determine whether any consistent interregional

TABLE 1

Comparison of Two Methods of Measuring Brain Edema: Tissue RISA and Wet/Dry Weights

WET:DRY WEIGHTS

TISSUE RISA

\pm S.D.

\begin{tabular}{|c|c|c|c|c|c|c|}
\hline AREA & $\begin{array}{l}\text { TISSUE } \\
\text { SOLIDS \% }\end{array}$ & $\begin{array}{l}\text { \% DECREASE IN } \\
\text { TISSUE SOLIDS }\end{array}$ & $\mathbf{P}$ & $\begin{array}{l}\text { EV PLASMA VOLUME } \\
\text { (EVPV) } \mathrm{ml} / 100 \mathrm{mg} \text { tissue }\end{array}$ & $\begin{array}{c}\text { EXCESS } \\
\text { (EVPV) } \\
\text { ml/100mg tissue }\end{array}$ & $\mathbf{P}$ \\
\hline UNOPERATED CONTROL & $\begin{array}{l}20.24 \\
\pm 0.83\end{array}$ & & & $\begin{array}{l}0.37 \\
\pm 0.13\end{array}$ & & \\
\hline $\begin{array}{l}\text { CONTRALATERAL (CONTROL) } \\
\text { HEMISPHERE (C) }\end{array}$ & $\begin{array}{l}20.31 \\
\pm 0.78\end{array}$ & & & $\begin{array}{l}0.75 \\
\pm 0.31\end{array}$ & & \\
\hline INJURED HEMISPHERE & $\begin{array}{l}19.18 \\
\pm 1.04\end{array}$ & 5.56 & $<0.00 \mathrm{l}$ & $\begin{array}{l}4.83 \\
\pm 1.24\end{array}$ & 4.08 & $<0.001$ \\
\hline FREEZE LESION (L) & $\begin{array}{l}18.58 \\
\pm 1.62\end{array}$ & 8.52 & $<0.001$ & $\begin{aligned} & 10.09 \\
& \pm 3.14\end{aligned}$ & 9.33 & $<0.001$ \\
\hline $\begin{array}{l}\text { IPSILATERAL ADJACENT } \\
\text { TO LESION }(\mathrm{A})\end{array}$ & $\begin{array}{l}19.61 \\
\pm 0.93\end{array}$ & 3.35 & $<0.005$ & $\begin{array}{l}1.97 \\
\pm 1.19\end{array}$ & 1.21 & $<0.001$ \\
\hline
\end{tabular}


difference in EVPV or tissue solids was detectable.

\section{RESULTS}

The results are summarized in Table 1. In the five unoperated control animals there was no difference in EVPV or tissue solids among the six hemispheric sections; the values for EVPV ranged from 0.32 to $0.41 \mathrm{ml}$ per $100 \mathrm{mg}$ wet weight, and tissue solids 19.86 to $20.56 \%$ of wet weight. EVPV in the control hemispheres of lesioned animals was $0.75 \pm 0.31 \mathrm{ml} / 100 \mathrm{mg}$ of wet weight while tissue solids were $20.31 \pm 0.78 \%$. This indicates that in these experiments the control hemispheres were relatively uninvolved in the edema process.

In the total injured hemisphere there was good agreement between $\mathrm{BE}$ calculated by the tissue RISA method (i.e. excess EVPV) and total excess water calculated from the percentage decrease in total tissue solids. This good correspondence between the two methods is also evident in section $\mathrm{L}$, the area of BBB breakdown delineated by Evans blue staining, but less impressive in sections $A$, the unstained poles of the hemisphere adjacent to $\mathrm{L}$.

\section{DISCUSSION}

It is evident that in section $L$ there is excess albumin, i.e. estimated EVPV in excess of the true water content determined gravimetrically; while in sections $A$ there is excess water, i.e. water in excess of that estimated as EVPV.

These relationships are more evident in Figure 2. Within section $L$ there is a good correlation between the two methods of estimating BE, but, although the straight line describing this relationship is roughly parallel to the line of identity, it is shifted to the right, indicating an excess of albumin in section $L$. On the other hand, the majority of sections A contain gravimetrically measured excess water but little RISA. The only reasonable explanation to account for these observations is that the rate of diffusion of water through the brain tissue exceeds that of albumin in the early stages of vasogenic BE formation, and that the origin of both the water and albumin in the tissue was the area of BBB breakdown of $L$.

\section{CORRELATION between RISA and WET : DRY WEIGHT METHODS}

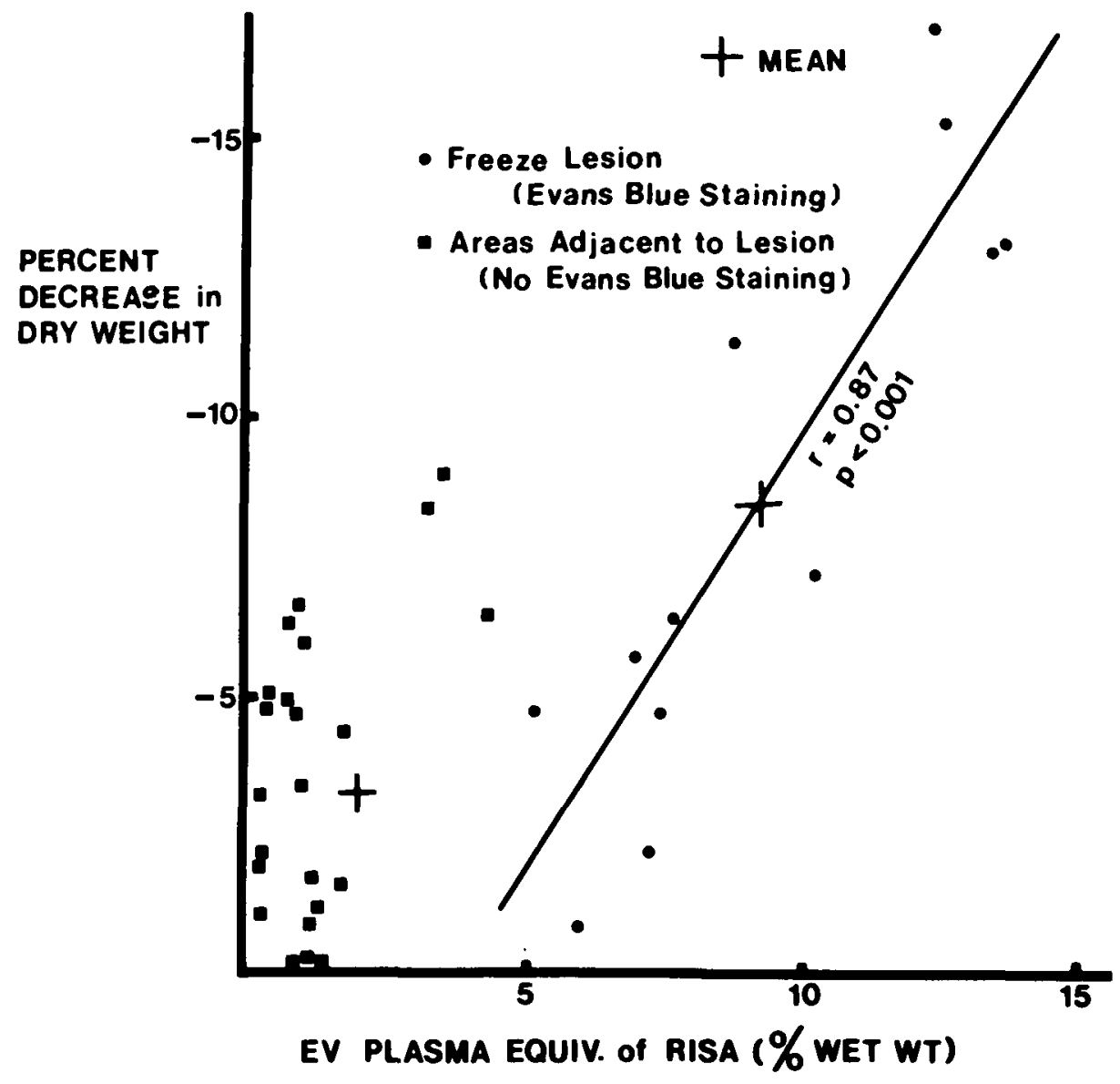

Figure 2 - Comparison of EVPV on X-axis and percent decrease in dry weight on the $\mathrm{Y}$-axis.

Several methods to estimate BE have been described. Only the gravimetric method (change in wet:dry weight ratios) is precise in quantitating total excess tissue water, but it does not distinguish between vasogenic (extracellular) and cytotoxic (intracellular) edema.

For example, Myers, et al. (1969) studied the effects of prolonged partial asphyxia on brain swelling in the Rhesus monkey fetus. However, they used gross, morphologic criteria for brain swelling, flattened convolutions, and herniation of the cerebellar tonsils.

Pappius and McCann (1969) studied unilateral brain edema produced by a cold injury. They compared the increase in RISA content in the edematous hemisphere with the difference in weight between the two hemispheres and found a good cor- relation between the two up to 24 hours. They corrected for intravascular RISA by subtracting the RISA counts in the control hemisphere from those in the edematous hemisphere. Our method is based on theirs, using RISA to estimate the total plasma content of the tissue, and $\mathrm{Cr}^{51}$ labelled red blood cells to calculate the intravascular blood and plasma volumes. This method accurately estimates vasogenic BE around a local (freeze injury) lesion during the acute phase of BE formation and can be used to quantitate bilateral edema.

The formation, spread, and resolution of vasogenic $B E$ around a local lesion is a dynamic process. The processes involved in spread and resolution of the edema fluid and its constituents include bulk flow, diffusion, capillary re-absorption, and metabolic degradation. Recent work 
by Reulen et al. (1978) suggests that the major mechanism for clearance of vasogenic $B E$ is bulk flow to the ventricular CSF under the influence of pressure gradients between the tissue and ventricular CSF.

To date little work has been reported in the early stages of vasogenic BE formation. Our studies indicate that appreciable BE develops rapidly, within 2 hours after a cold injury lesion, and that, initially at least, the rate of water diffusion laterally from the lesion exceeds that of albumin. It was, of course, not surprising that albumin was not found beyond the border of Evan's blue staining, since Evan's blue is albumin bound. However, the unstained tissue had accumulated considerable excess water by this time. The method, therefore, only accurately estimates water content of the injured tissue in the very early stages of formation.

This method can now be used to study therapeutic interventions in the process of vasogenic BE formation.

\section{ACKNOWLEDGEMENTS}

This work was supported by the Medical Research Council of Canada and by the Manitaba Heart
Foundation. The technical expertise of Mr. Wayne Pucci and Miss Maureen Cumming are gratefully acknowledged.

\section{REFERENCES}

MYERS, RONALD E., BEARD, $R$. and ADAMSONS, K. (1969). Brain swelling in the newborn rhesus monkey following prolonged partial asphyxia. Neurology, 19. 1012-1018.

PAPPIUS, HANNA M. and McCANN, W.P. (1969). Effects of steroids on cerebral edema in cats. Arch. Neurol., 20, 207-216.

REULEN, HANS J., et al. (1978). Clearance of edema fluid into cerebrospinal fluid. $J$. Neurosurg., 48, 754-764. 